\section{Characterization of}

\section{alkali activated geopolymer mortar doped with MWCNT}

HISHAM M. M. KHATER - Housing and Building National Research Centre (HBNRC)

- hkhater4@yahoo.com

Hamdy A. Abdel GAWWAD - Housing and Building National Research Centre (HBNRC))

- hamdyabdelgawwad@yahoo.com

Érkezett: 2015. 03. 28. - Received: 28. 03. 2015. " http://dx.doi.org/10.14382/epitoanyag-jsbcm.2015.7

\section{Abstract}

This paper aimed to investigate the effect of multi-walled carbon nanotubes (MWCNT) on properties of slag geopolymeric mortar. Geopolymeric matrices containing different MWCNTs concentrations $(0.0,0.1,0.2,0.3$ and $0.4 \%$ by weight of the used binder) were synthesized. The geopolymer mortar composed of aluminosilicate slag to sand (1:2), while the aluminosilicate source binder composed of 50\% air cooled slag and 50\% water cooled slag both passing a sieve of $90 \mu \mathrm{m}$, while the sand passing a sieve of $1 \mathrm{~mm}$. The materials prepared at water/binder ratios in a range of 0.34-0.39\% depending on the added MWCNT, whereas the Glenium Ace-30 superplasticizer used in the ratio of 1.4-2.2\% from the total dry weight for better dispersion of MWCNT under sonication for $15 \mathrm{~min}$. Alkaline activation of the geopolymer mortar was carried by using of $6 \% \mathrm{NaOH}$. Curing was performed under temperature of $40^{\circ} \mathrm{C}$ and $100 \%$ relative humidity. Results showed that the addition of MWCNTs enhanced the resulting amorphous geopolymer structure with marked decrease in the drying shrinkage as well as water absorption specially when using $0.1 \%$ MWCNT, while further increase in MWCNTs results in agglomeration in MWCNT within the matrix and so hinder the propagation of geopolymerization reaction and negatively affect the formed geopolymer structure.

Keywords: MWCNT, geopolymer, mortar, water cooled slag, air cooled slag.
Hisham Mustafa Mohamed KHATER Ph.D. in Physical Chemistry, 2009. Associated Professor in Cement chemistry and Raw Building Materials Technology and Processing since 2015 Researcher in Raw Building Materials Technology and Processing Research Institute, Housing and Building National Research Center (HBRC). Supervisor of XRF laboratory for the chemica analysis of all type of raw building materials, accredited from International American Service IAS 17025 since 2005. Research interest: X-ray fluorescence spectroscopy, X-ray diffraction Fourier Tranformer-IR spectroscopy, differentia thermal analysis, chemical analysis of cements, recycling of waste materials, assessment of clay minerals, low cost and environmentally green building materials, nanotechnology in building materials. Author of more than 20 papers.

Hamdy A. Abdel GAWWAD Researcher in Raw Building Materials Technology and Processing Research Institute, Housing and Building National Research Center (HBRC). Research interest: alkali activated geopolymers, carbon nano-tubes, supplementary cementing materials.

\section{Introduction}

Nanoparticles have proven to be an effective reinforcement in a variety of cement composites [1-3]. When fine aggregate particles are dispersed in the cement paste, they generate large number of nucleation sites causing the paste more homogeneous and dense as for the distribution of the fine pores. In addition, the physical effect of the fine grains allows denser packing within the cement and reduces the wall effect in the transition zone between the paste and aggregate. This weaker zone is strengthened due to the higher bond developed between these two phases, improving the microstructure and properties. Therefore, the addition of nanoparticles to cement composite increases its mechanical strength and durability when compared to the blank paste.

Recently, carbon nanotubes (CNT) have shown a high potential to improve the properties of materials. Since discovery of CNT by Iijima in 1991 [4], it has been widely used for a variety of applications due to their excellent physical properties: high strength, and Young's modulus of individual CNT is about 1.8 TPa [5]. CNT exhibits great mechanical properties along with extremely high aspect ratios (length-to-diameter ratio) ranging from 30 to more than many thousands. They are expected to produce significantly stronger and tougher cement composites than traditional reinforcing materials (e.g. glass fibers or carbon fibers). In fact, because of their size (ranging from $1 \mathrm{~nm}$ to $10 \mathrm{~nm}$ ) and aspect ratios, CNT can be distributed in a much finer scale, resulting more efficient crack bridging at the very preliminary stage of crack propagation within cement composites. However, properties and dimensions of
CNT strongly depend on the deposition parameters and the nature of the synthesis method, i.e., arc-discharge [6], laser ablation [7], or chemical vapor deposition (CVD) [8]. In view of a commercial application, the arc-discharge technique is the only one that can offer a path towards low-cost and large scale production $[9,10]$.

In fact, $\mathrm{CNT}$ obtained with a complete graphitization process achieved by heat-treatment at high temperature [11], either in vacuum or inert environment, show outstanding mechanical properties [12]. When fine aggregate particles are dispersed in the cement paste, they generate large number of nucleation sites causing the paste more homogeneous and dense as for the distribution of the fine pores. In addition, the physical effect of the fine grains allows denser packing within the cement and reduces the wall effect in the transition zone between the paste and aggregate. This weaker zone is strengthened due to the higher bond developed between these two phases, improving the microstructure and properties. Therefore, the addition of nanoparticles to cement composite increases its mechanical strength and durability when compared to the neat paste.

Geopolymer-based composites are a novel class of lowembodied carbon binders formed by a combination of lowcalcium fly ash (FA) and alkaline solution. The curing process of geopolymer known as polymerization where the aluminosilicate oxides react with the alkali polysilicates to form a 3-dimensional polymeric $\mathrm{Si}-\mathrm{O}-\mathrm{Al}$ amorphous microstructure $[13,14]$. Geopolymers are currently being considered as a replacement to ordinary Portland cement (OPC) and has received considerable attention for their cost efficiency, chemical stability, corrosion resistance, rapid strength gain rate, 
low shrinkage and freeze-thaw resistance $[15,16]$. However, due to their cross-linked structure, geopolymer tend to be more brittle than OPC and therefore, they are unsuitable for structural applications when safety-based structural design is considered. Geopolymers were found to be more brittle than the OPC, and their fracture energy was about $40 \%$ of that of OPC [17]. Thus, improvement in fracture properties of geopolymer is deemed necessary. Previous research investigated the mechanical properties of geopolymer reinforced with different macro-fibers such as steel, polypropylene (PP), polyvinyl chloride (PVC) and basalt fibers [18].

The addition of these fibers increased the flexural strength, fracture energy and controlled the crack propagation [18]. Carbon nanotubes are being considered as a potential reinforcement in composites because they have mechanical, electrical, chemical and thermal properties superior to traditional fibers [19]. Nanoscale reinforcement of OPC with CNTs has been the focus of intense study recently. Chen et al. [20] provided complete literature review of CNT-cement nanocomposites. Their review focused on the effect of CNTs on the properties of OPC including fabrication, hydration, mechanical properties, porosity and transport, conductivity and piezoresistivity. It was found that the dispersion of CNTs in cement remains one of the main challenges in improving the fabrication of CNT-OPC mixtures. Adequate dispersion of CNTs in cement is challenging since van der Waals forces are responsible for their bundling and agglomeration even at very low concentrations, thereby limiting their potential benefits [20-22].

The enhancement of mechanical and electrical properties depends on how well the CNTs are dispersed within the cement matrix. The literature review highlighted many inconsistent results on the effect of CNTs on the mechanical properties of OPC. However, it is well established that the current mechanical properties of CNT-OPC are not satisfactory for structural applications indicating further research is needed to find ways to uniformly disperse CNTs in cement [20]. In terms of durability, previous studies on the effect of CNTs on the pore structure of CNT-OPC composites suggested that CNTs can act as nucleating sites for the cement hydration and as a result, the overall porosity and pore continuity are reduced [20]. The addition of CNTs improves the multifunctional properties of OPC. Well dispersed CNTs increase the conductivity and piezoresistivity sensitivity of CNT-OPC composites. This is attributed to the formation of conductive network in the cement matrix. In this case, the CNT-OPC exhibits an enhanced ability to sense its own damage based on the change in the electrical change upon loading [20]. A few studies have focused on the fabrication of CNT-OPC composites in relation to dispersion of CNTs and workability of mixtures. Collins et al. [23] conducted a comprehensive study aimed at investigating the effect of different types of dispersion agents on the dispersion of CNTs and workability of CNTOPC composites. Polycarboxylate-based superplasticizer and lignosulfonate dispersant agents provided adequate dispersion of CNTs (up to $0.5 \mathrm{~m} \% \mathrm{CNTs}$ ) whereas styrene butadiene rubber and calcium naphthalene sulfonate dispersant agents promoted the agglomeration of CNTs. The addition of CNTs reduced the consistency and strength of CNT-OPC mixtures. This reduction was significant for mixtures with CNT contents of 1 and $2 \mathrm{~m} \%$. This is consistent with the results from previous studies $[24,25]$ where in order to achieve adequate dispersion of CNTs within the cement paste, a maximum content of 0.1 $\mathrm{m} \%$ was recommended [24].

The mechanical and electrical properties of FA-based geopolymers containing carbon nanotubes have not been reported apart from similar potassium-based aluminosilicate (clay) geopolymer reinforced with single walled carbon nanotubes (SWCNTs) [26].Their investigation showed that the conductivity increased with increasing SWNCT content, whereas the tensile strength results were inconsistent. The tensile strength slightly decreased at $0.2 \mathrm{~m} \%$ SWCNTs and increased at $0.25 \mathrm{~m} \%$ SWCNTs, and then sharply decreased at $0.35 \mathrm{~m} \%$ SWCNTs. Although it has not previously been investigated, the alkaline solution used to process geopolymer has the potential to enhance the interaction of MWCNTs with the geopolymeric matrix by two positive effects, leading to improved mechanical and electrical properties. The first one is the effect of sodium hydroxide $(\mathrm{NaOH})$ on the dispersion of MWCNTs within the geopolymeric matrix. Previous studies have shown that $\mathrm{NaOH}$ acts as a surfactant and removes the oxidation debris from the surface of CNTs and consequently allowing them to de-bundle and form well-dispersed nanotubes within the matrix [27]. The other is the effect of $\mathrm{NaOH}$ on the electrical conductivity of the geopolymer. The pores solution of $\mathrm{NaOH}$ in the form of electrolytes allow the electrons to easily move within the matrix, resulting in an improved conductivity which could be enhanced further by integrating CNTs into the matrix to develop self-sensing structural materials. With an electrical conductivity between 0.05 and $0.1 \mathrm{~S} / \mathrm{m}$, fly ash-based geopolymers are considered as semiconductor materials [28].

The object of this study is to examine the mechanical, mineralogical, geopolymer functionality using FTIR, water absorption and drying shrinkage of the resulted geopolymeric nanocomposites mortars reinforced with various ratios of MWCNTs as new multifunctional structural materials, also, the dispersion quality of MWCNT was evaluated and the improvement in mechanical properties of geopolymer nanocomposites was quantified.

\section{Experimental procedures}

\subsection{Materials}

The materials, which were used in this investigation, are ground granulated water cooled blast furnace slag (WCS), air cooled slag sourced from Iron and Steel Factory- Helwan, Egypt. The used sand dunes for mortar preparation sourced from fine sand (<1 mm) from Oases (Wahat)-Road, Egypt. The chemical compositions of the starting raw materials are given in Table 1. Sodium hydroxide was used as alkali activators. Sodium hydroxide $(\mathrm{NaOH})$ produced by Fisher scientific company with $99 \%$ purity. The mineralogical composition represented in Fig. 1; where ground granulated blast furnace slag materials composed of amorphous materials and air cooled slag composed of crystalline minerals of quartz and gehlenite. 


\begin{tabular}{|c|c|c|c|c|c|c|c|c|c|c|c|c|c|c|c|c|}
\hline $\begin{array}{l}\text { Oxide content } \\
\text { (\%) }\end{array}$ & $\mathrm{SiO}_{2}$ & $\mathrm{Al}_{2} \mathrm{O}_{3}$ & $\mathrm{Fe}_{2} \mathrm{O}_{3}$ & $\mathrm{CaO}$ & Mgo & $\mathrm{SO}_{3}$ & $\mathrm{~K}_{2} \mathrm{O}$ & $\mathrm{Na}_{2} \mathrm{O}$ & $\mathrm{TiO}_{2}$ & Mno & $\mathbf{P}_{2} \mathbf{O}_{5}$ & CI- & Sro & $\mathrm{BaO}$ & L.O.I. & Total \\
\hline $\begin{array}{l}\text { Air cooled Slag } \\
\text { (ACS) }\end{array}$ & 38.11 & 9.31 & 4.06 & 35.23 & 2.22 & 2.00 & 0.66 & 0.45 & 0.45 & 3.29 & 0.09 & 0.07 & 0.14 & 3.75 & 0.13 & 99.94 \\
\hline $\begin{array}{l}\text { Water cooled Slag } \\
\text { (WCS) }\end{array}$ & 36.67 & 10.31 & 0.50 & 38.82 & 1.70 & 2.17 & 1.03 & 0.48 & 0.57 & 4.04 & 0.04 & 0.05 & 0.18 & 3.28 & 0.12 & 99.96 \\
\hline $\begin{array}{l}\text { Fine Sand } \\
\text { (Sand dunes) }\end{array}$ & 89.91 & 2.00 & 1.45 & 1.56 & 1.91 & 0.87 & 0.37 & 0.06 & 0.03 & 0.04 & 0.03 & 0.12 & - & - & 1.65 & 99.98 \\
\hline
\end{tabular}

Table 1. Chemical composition of starting materials ( $m \%)$

1. táblázat A kiindulási anyagok kémiai összetétele ( $m \%)$

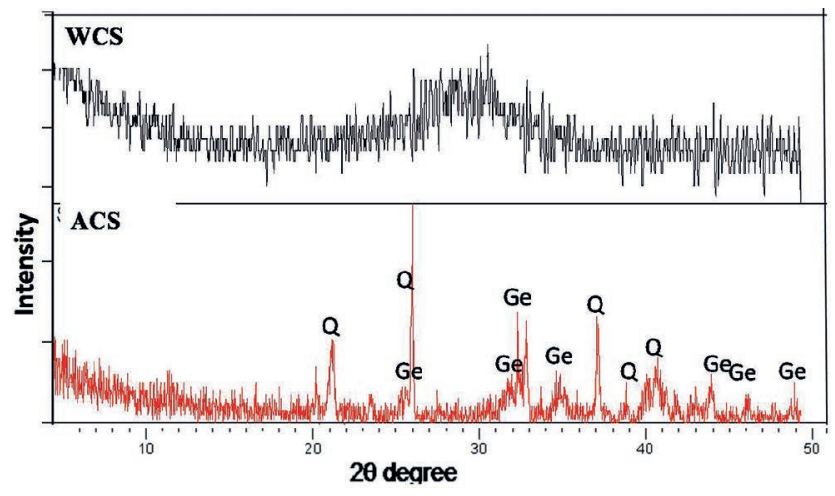

Fig. 1. Mineralogical composition of starting raw materials [Q: Quartz $\left(\mathrm{SiO}_{2}\right)$, Ge: Gehlenite ' $\left.\mathrm{C}_{2} \mathrm{ASH}_{8}\right)$ ]

1. ábra A kiindulási alapanyagok ásványi összetétele [Q: $\operatorname{Kvarc}\left(\mathrm{SiO}_{2}\right.$ ), Ge: Gelenit ' ${ }^{\circ} \mathrm{ASH}_{2}$ )]

Carbon nanotubes which used for enhancing of geopolymeric mortar are of multiwall type consisting of many nested cylinders whose successive radii differ by roughly the interlayer spacing of graphite. The morphologies and microstructures of the as-synthesized carbon nanomaterials were characterized by transmission microscope (TEM), as shown in Fig. 2, which depicts the representative TEM image of as-synthesized carbon nanotubes deposited on $50 \% \mathrm{Co} / \mathrm{MgO}$ by acetylene gas decomposition at $700{ }^{\circ} \mathrm{C}$ reaction temperature and $\sim 4$ h timeon-stream. These images show that the morphologies have tubular structures, i.e. they are multi-walled carbon nanotubes (MWCNTs) and the boundaries between MWCNT tubes are clear. The diameters of the MWCNTs are mostly in the range of 14-24 nm. It is obvious in Fig. 2. $a$ and $2 . b$ the dark object in the pictures is related to the Co - metal particles of the catalyst.

Raman spectroscopy was employed to analyze the degree of graphitization of the produced CNTs as represented in Fig. 2.c; where the two major bands were observed, representing D- and G-bands. The D-band, observed at $1250-1350 \mathrm{~cm}^{-1}$, is known as either the disorder induced due to the wall disorder or the presence of amorphous carbon deposited on the outer surface of nanotubes. The G-band (observed at 1550-1600 $\mathrm{cm}^{-1}$ ) can be attributed to the degree of graphitization of CNTs. The ratio of ID/IG of the D and G-band can be regarded as an index for the crystalline order of CNTs; the high ID/IG value $(>1)$ indicates that there is high structural disorder in the carbon nanotubes obtained on the catalysts. However the lower ID/ IG value $(<1)$ suggests the enhancement in graphitization of deposited carbon. The high intensity of the G-band $(417 \mathrm{~cm}-1)$ relative to $\mathrm{D}$-band $\left(270.7 \mathrm{~cm}^{-1}\right)(\mathrm{ID} / \mathrm{IG}$ ratio $\approx 0.65)$ suggests that the CNTs synthesized under the optimum conditions were highly graphitized [29].
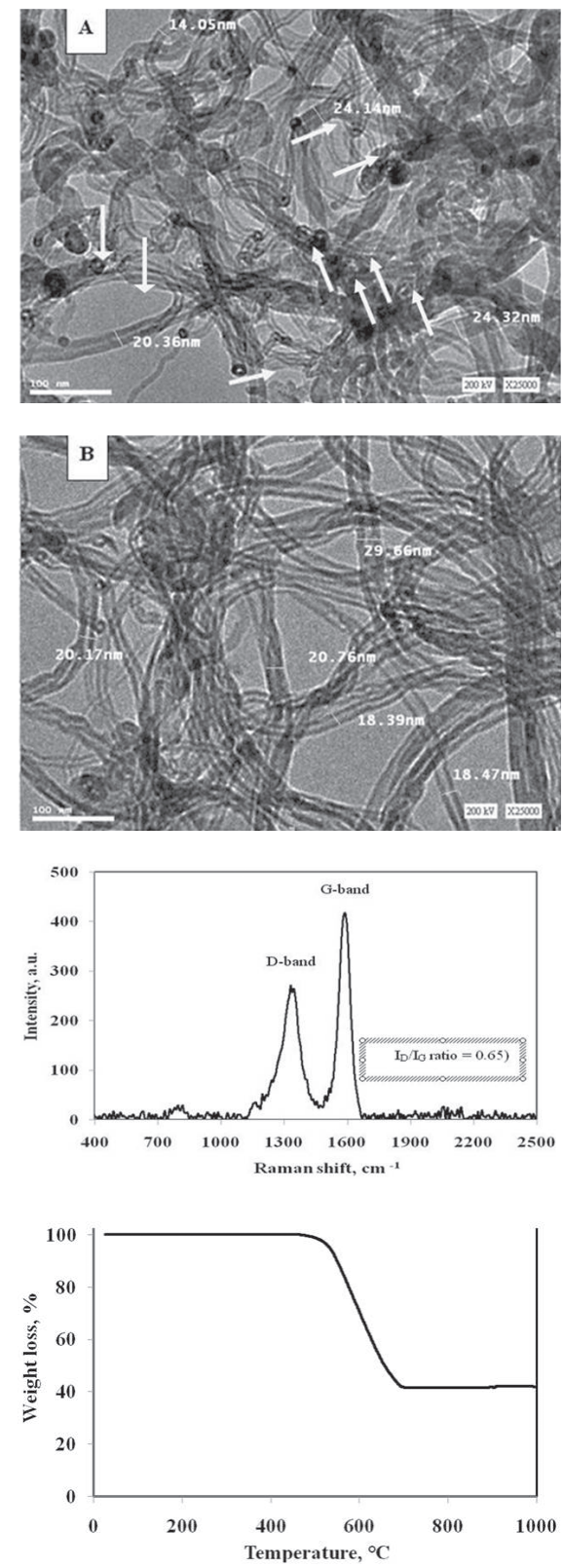

Fig. 2. Characterization of synthesized multiwall carbon nanotube $a, b)$ TEM pictures of catalysts after growth of CNTs using $50 \% \mathrm{Co} / \mathrm{MgO}$ catalyst, with high magnification

c) Raman spectroscopy of CNTs over $50 \% \mathrm{Co} / \mathrm{MgO}$ catalyst

d) Thermal gravimetric analysis after growth of CNTs using Co/MgO catalyst

2. ábra A szintetizált többfalú szén nanocső jellemzői

a, b) TEM felvételek nagy nagyításban, az 50\% Co/MgO katalizátor mellet növelt nanocsövekröl

c) Raman spektroszkópia az 50\% Co/MgO katalizátor mellet növelt nanocsövekröl

d) Termogravimetria az 50\% Co/MgO katalizátor mellet növelt nanocsövekröl 
Thermo-gravimetric analysis (TGA) is very important tool for clarifying the yield, stability and quality of the asgrown MWCNTs, as indicated in Fig. 2.d where the catalyst presented a single oxidation inflection, which indicates that the amorphous carbon is extremely low and high purity MWCNTs are produced, also, TGA data determine the onset, and offset (end) temperatures represent the temperature at the initial weight loss, $\left(496^{\circ} \mathrm{C}\right)$ and the final weight loss, $\left(692^{\circ} \mathrm{C}\right)$ respectively. The large difference between the onset and end temperature $\left(192{ }^{\circ} \mathrm{C}\right)$ is attained on the catalyst. This can be attributed to the formation of large diameters of CNTs, which are proved by TEM photos (Fig. 2.a and 2.b). Based on these results, the formation of ideal graphitized carbon nanomaterials and the highest carbon yield are gained on it. The properties of the produced MWCNT are summarized in Table 2.

\begin{tabular}{lcc} 
Item & Property & Results \\
$\mathbf{I}$ & Outer diameter $(\mathrm{nm})$ & $20-30$ \\
\hline $\mathbf{2}$ & Inner diameter (nm) & 4 \\
\hline $\mathbf{3}$ & Purity wt. (\%) & 97 \\
\hline $\mathbf{4}$ & Length (mm) & $1-5$ \\
\hline $\mathbf{5}$ & Ash (\%) & 3 \\
\hline $\mathbf{6}$ & Amorphous (\%) & 0 \\
\hline $\mathbf{7}$ & Field (\%) & 800
\end{tabular}

Table 2. Properties of CNTs synthesized by using CVD apparatus 2. táblázat CVD készülékkel szintetizált nanocsövek tulajdonságai

\subsection{Dispersion of MWCNTs}

Since the strong Van der Waals forces cause the agglomeration of the nanoparticles, a key issue in fabricating high-quality nanotubes composite is to homogeneous the nano carbon materials in cementitious materials. Poor dispersion will lead to the formation of defects in the matrix and limit the nanoenhancement/modification effect [30]. A lot of research work has been done to improve the dispersion of Nano carbon materials (NCM) in the cementitious composites. Commonly, there are two types of methods used to disperse NCMs. Mechanical separation of the NCMs by adopting ultrasonic is one of the effective methods for CNT dispersion [31-33]. Recently, researchers have proposed some novel approaches to solve the dispersion issue of NCMs. The primary approach is to adopt commonly used water reducing admixtures (including plasticizers and superplasticizer) as surfactants. The research at the National Research Council Canada has shown that a small amount of CNTs can be dispersed by ultrasonication in the water containing 5\% superplasticizer [34]. Shah et al. also achieved an effective dispersion of MWCNTs with different lengths and concentrations in cementitious materials by applying polycarboxylate-based superplasticizer [35].

In the current work, MWCNTs were first mixed with Glenium Ace 30-polycarboxylate-based superplasticizer and 50\% of the added water. This Polycarboxylate-based superplasticizer has been proven to be effective for CNTs dispersion [36]. The solution was sonicated using a Fritish 450 Sonifier Analog Cell Distributor for $15 \mathrm{~min}$ [37]. Solutions with concentration of
$0.1,0.2,0.3$, and $0.4 \mathrm{~m} \%$ of the total weight of the matrix were used to identify the MWCNT concentrations for the evaluation of the threshold ratio of MWCNT.

\subsection{Geopolymerization and curing}

The alkaline activator was composed of $6 \mathrm{~m} \% \mathrm{NaOH}$, which prepared 24 hrs prior to casting. Geopolymer mortar reinforced with MWCNT concentrations: 0.0 (control), 0.1 , $0.2,0.3$, and $0.4 \mathrm{~m} \%$ of the total weight.

Accordingly, mixing was performed by hand-mixing of raw materials for each mixture passing a sieve of $90 \mu \mathrm{m}$ as represented in Table 2 according to the following sequence:

1. The previously prepared MWCNT particles sonicated for 15 min with $50 \%$ of the added water and the specified quantity of the superplasticizer for better dispersion of nanotubes materials under a temperature of $40{ }^{\circ} \mathrm{C}$.

2. The geopolymer materials passing a sieve of $90 \mu \mathrm{m}$ as represented in Table 2 were hand mixed with the alkaline activator solution which dissolved in the remaining water content for 10 minute followed by a further 5 minute using rotary mixer and mixed at medium speed ( $80 \mathrm{rpm})$ for another $30 \mathrm{~s}$.

3. The MWCNT and superplasticizer were added and stirred with mixture at high speed for additional $30 \mathrm{~s}$.

4. The mixture was allowed to rest for $90 \mathrm{~s}$ and then mixed for $1 \mathrm{~min}$ at high speed.

The paste mixture was cast into $25 \times 25 \times 25 \mathrm{~mm}$ cubicshaped moulds, vibrated for compaction and sealed with a lid to minimize any loss of evaporable water. All mixes were left to cure undisturbed under ambient temperature for 24 hrs, demolded and then subjected to curing at $40{ }^{\circ} \mathrm{C}$ with $100 \%$ relative humidity [38]. At the end of the curing regime, the specimens were subjected to the compressive strength measurements and then the resulted crushed specimens were exposed to stopping of the hydration process using stopping solution of alcohol/acetone (1:1) followed by washing with acetone as recommended by different investigators [39, 40] to prevent further hydration and for further analysis followed by drying of the crushed specimens for $24 \mathrm{hrs}$ at $80^{\circ} \mathrm{C}$, then preserved in a well tight container until the time of testing.

\begin{tabular}{ccccccc}
$\begin{array}{c}\text { Mix } \\
\text { no. }\end{array}$ & $\begin{array}{c}\text { Water } \\
\text { cooled } \\
\text { slag, } \\
\%\end{array}$ & $\begin{array}{c}\text { Air } \\
\text { cooled } \\
\text { slag, } \\
\%\end{array}$ & $\begin{array}{c}\text { Sand } \\
\text { dunes, } \\
\%\end{array}$ & $\begin{array}{c}\text { MWCNT } \\
\text { addition } \\
\text { from the } \\
\text { added } \\
\text { binder, } \%\end{array}$ & $\begin{array}{c}\text { W/B } \\
\text { ratio, } \\
\%\end{array}$ & $\begin{array}{c}\text { Super- } \\
\text { plasticizer } \\
\text { of the } \\
\text { total wt., } \\
\%\end{array}$ \\
\hline $\mathbf{R}$ & 16.7 & 16.7 & 66.6 & 0.0 & 0.34 & 1.4 \\
\hline $\mathbf{1}$ & 16.7 & 16.7 & 66.6 & 0.1 & 0.34 & 1.6 \\
\hline $\mathbf{2}$ & 16.7 & 16.7 & 66.6 & 0.2 & 0.34 & 1.8 \\
\hline $\mathbf{4}$ & 16.7 & 16.7 & 66.6 & 03 & 0.39 & 2.0 \\
\hline
\end{tabular}

Table 3. Composition of the geopolymer mixes $(m \%)$

3. táblázat A geopolimer keverékek összetétele ( $m \%$ ) 


\subsection{Methods of investigation}

Chemical analysis was carried out using Axios (PW4400) WD-XRF Sequential Spectrometer (Panalytical, Netherland). Compressive strength tests were carried out using five tones German Brüf pressing machine with a loading rate of $100 \mathrm{~kg} /$ min determined according to [41]. XRD analysis was recorded on a Philips PW 1050/70 Diffractometer using a Cu-Ka source with a post sample $\mathrm{Ka}$ filter. XRD patterns were collected from $0^{\circ}$ to $50^{\circ} 2 \Theta$ (step size $0.02^{\circ} 2 \Theta$ and speed $0.4^{\circ} / \mathrm{min}$ ). Silica was used as an internal standard. Data were identified according to the XRD software (pdf-2: database on CDRelease 2005). Removal of free water was accomplished by using alcohol/acetone method as recommended by different investigators [39-40]. Drying shrinkage test was carried out on dried at $110^{\circ} \mathrm{C}$ for 24 hours to ensure total water loss. The test specimens were then measured (in terms of dimension) and their values were noted as dry lengths and calculated for each test specimen using the following formula $[42,43]$ :

$\%$ Average Drying Shrinkage $=(O L-D L) / O L^{*} 100$

where: OL means original length; DL stands for dry length

Water absorption measurements of the bricks were carried out according to ASTM C140-01 [44]. The percentage absorption was calculated using the equation:

Absorption $(\%)=[(W 2-W 1) / W 1] \times 100$

where $\mathrm{W} 1=$ weight of specimen after complete drying at $105^{\circ} \mathrm{C}$, $\mathrm{W} 2$ = final weight of surface dry sample after immersion in water for at least 24 hours.

Bonding characteristics of the alkali activated specimens were analyzed using a Jasco-6100 Fourier transformed infrared spectrometer FTIR. Test sample was ground and uniformly mixed with $\mathrm{KBr}$ at a weight ratio $\mathrm{KBr}$ : specimen=200:1. The mixture, $0.2 \mathrm{~g}$ was pressed to a disk of $13 \mathrm{~mm}$ in diameter for analysis at $8 \mathrm{t} / \mathrm{cm}^{2}$. The wave number was ranging from 400 to $4000 \mathrm{~cm}^{-1}[45,46]$.

\section{Results and discussion}

XRD pattern of alkali-activated geopolymer mortar mixes without MWCNT at different hydration ages is shown in Fig. 3. The patterns illustrate a hump in the region of $17^{\circ}$ to $35^{\circ} 2 \theta$ characterizing glassy phase of the geopolymer constituents, this region considered as vital key in geopolymer characterization, where any increase in this hump will be reflected on the performance and efficiency of the resulting geopolymer gel as the amorphous constituents increase with this hump. It can be noticed an increase in the broadness and intensity of CSH band up to 90 days, as indicated from the increased broadness at $29.4^{\circ}$ where the identification of $\mathrm{C}-\mathrm{S}-\mathrm{H}$ type phases is consistent with the observations presented in other studies [47].

The formation of $\mathrm{C}-(\mathrm{N})-\mathrm{S}-\mathrm{H}$ type gels has been observed at about $33^{\circ}(2 \Theta)$ in $\mathrm{NaOH}$-activated slags [48] as an inner binding product formed around partially reacted slag particles, and in silicate-activated slags after longer times of curing [48]. The formation of this gel might be associated with the increased availability of $\mathrm{Na}^{+}$in the pores of the young $\mathrm{C}-\mathrm{S}-\mathrm{H}$ type gel formed at early age immediately surrounding the unreacted slag particles. Formation of Ca-containing-S-H type gels has also been identified during the addition of $\mathrm{NaOH}$ to fresh synthetic C-S-H type gels [49] and in blends of synthetic $\mathrm{N}-\mathrm{A}-\mathrm{S}-\mathrm{H}$ and $\mathrm{C}-\mathrm{S}-\mathrm{H}$ type gels [50].

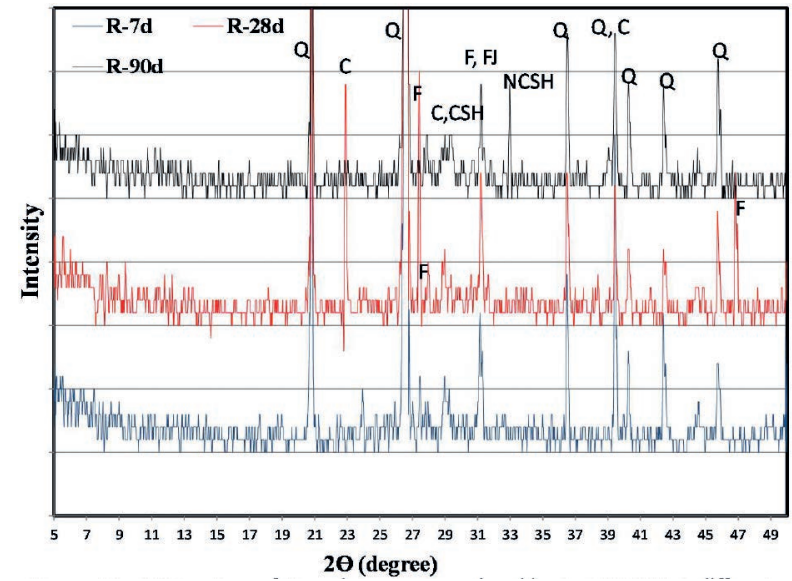

Fig. 3. XRD pattern of geopolymer mortar mix without MWCNT at different curing ages

[Q: Quartz, F: Feldspar, C: Calcite, CSH: Calcium-silicate-hydrate, NCSH: Sodium-calcium-silicate-hydrate, FJ: Faujasite of Zeolite NAS $\left.H_{\text {G }}\right]$

3. ábra Geopolimer habarcsok röntgendiffraktogramjai különböző korokban, szén nanocső adagolás nélkül

[Q: Kvarc, F: Földpát, C: Kalcit, CSH: Kalcium-szilikát-hidrát, NCSH: Nátrium-kalcium-szilikát-hidrát, FJ: Faujazit - Zeolit módosulat $\left.\mathrm{NAS}_{2.4} \mathrm{H}_{6.7}\right]$

However, the $\mathrm{C}-\mathrm{S}-\mathrm{H}$ structure formed in the presence of high concentrations of $\mathrm{NaOH}$ was less dense than the normal C-S-H structure resulting from hydration of Portland cement as reported Bakharev et al. [51]. It is also possible to form structures in which the sodium is incorporated into the structure of the hydrated silicate gel (N-C-S-H), as has been described by Malolepszy [52].

Crystalline Faujasite of zeolite was also observed at later ages of curing where the amorphous geopolymer transferred into crystalline one with little evident of increased reactivity. It is likely that a significant proportion of the $\mathrm{Na}^{+}$is consumed in the activation of slag mortar constituents to form a sodium aluminosilicate-type gel, reducing the availability of $\mathrm{Na}^{+}$species in the pore solution [53] and therefore reducing the alkalinity from the high levels which would favor zeolite growth, even with the higher alkali dosage added to these samples, also the increased intensity of N-C-S-H results in the decrease in the available balancing cations for geopolymer structure and so favour the Faujasite formation. It can also be noticed a slight increase in calcite content with time which may be probably resulting from reactions involving atmospheric $\mathrm{CO}_{2}[54]$.

On the other hand, XRD of 90 days nanocomposites with MWCNT concentrations of 0.1 and $0.4 \mathrm{~m} \%$ (Fig. 4) displayed a good dispersion up to $0.1 \%$, as the individual MWCNTs along with Polycarboxylate based superplasticizer are known to decrease the hydration speed in cementitious systems. The incorporated MWCNTs increase the hydration speed after addition to the same system, so the MWCNTs inhibit the retardation by the superplasticizer. This can also be explained by their ability to work as a nucleation-site in the system. The functionalized MWCNTs provide different reaction sites for the crystal growth. As known from literature hydration products grow on the surface of carbon nanotubes [55]. CSH-phases bind to the MWCNTs at the Carboxyl-sites by interaction 
of the $\mathrm{Ca}^{2+}$-ions of the pore solution. Therefore the carboxyl group-density on the surface of the MWCNTs can influence chain lengths of the grown $\mathrm{CSH}$-phases. With this reaction the MWCNTs work as a kind of template during hydration. The increase in CSH-phases attributed to the effect of the $\mathrm{NaOH}$ alkaline solution during processing as discussed in [27].

The carboxylate based superplasticizer was ineffective in dispersing MWCNTs at $0.3 \mathrm{~m} \%$ and more, where most of MWCNT were agglomerated in the alumino-silicate gel and hinder the propagation of the three dimensional network. This confirmed well by the increased Faujasite formation with the increased MWCNT, as the geopolymer network was terminated forming the crystalline Faujasite structure with lower reactive characteristics. A noticeable increase in carbonate with MWCNT addition beyond $0.1 \%$, which related to the increased agglomeration of nanomaterials with increased MWCNT and so many points of defects are available for carbonation, however lower doses acts as a nucleating agents and accelerate geopolymer formation and accumulation which in turn reflects on decreasing the medium porosity.

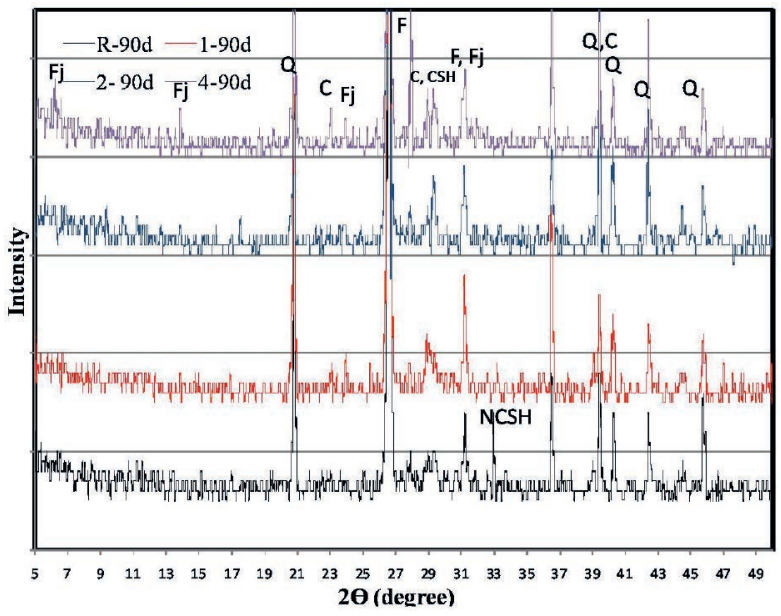

\footnotetext{
Fig. 4. XRD pattern of 90 days geopolymer mortar mixes having various MWCNT doses

[Q: Quartz, F: Feldspar, C: Calcite, CSH: Calcium-silicate-hydrate, NCSH: Sodium-calcium-silicate-hydrate, FJ: Faujasite of Zeolite $\left.\mathrm{NAS}_{2.4} \mathrm{H}_{6.7}\right]$

4. ábra Geopolimer habarcsok röntgendiffraktogramjai 90 napos korban, különbözö szén nanocső adagolások esetén

[Q: Kvarc, F: Földpát, C: Kalcit, CSH: Kalcium-szilikát-hidrát, NCSH: Nátrium-kalcium-szilikát-hidrát, FJ: Faujazit - Zeolit módosulat $\left.\mathrm{NAS}_{2.4} \mathrm{H}_{6.7}\right]$
}

FTIR spectra of alkali-activated geopolymer mixes have a bands description as follow: Stretching vibration of $\mathrm{O}-\mathrm{H}$ bond at about $3430,1600 \mathrm{~cm}^{-1}$, stretching vibration of $\mathrm{CO}_{2}$ located at about1410 $\mathrm{cm}^{-1}$, asymmetric stretching vibration ( $\mathrm{Si}-\mathrm{O}-\mathrm{Si}$ ) related to non-solubilized particles at about 1100 $\mathrm{cm}^{-1}$, asymmetric stretching vibration (T-O-Si) at about 975 $\mathrm{cm}^{-1}$ where $\mathrm{T}=\mathrm{Si}$ or $\mathrm{Al}$, symmetric stretching vibration of $\mathrm{CO}_{2}$ at about $870 \mathrm{~cm}^{-1}$, symmetric stretching vibration of ( $\left.\mathrm{Si}-\mathrm{O}-\mathrm{Si}\right)$ attributed to $\alpha$-quartz at about $797 \mathrm{~cm}^{-1}$, symmetric vibration at about $778 \mathrm{~cm}^{-1}$ for (Al-O-Si), symmetric stretching vibration ( $\mathrm{Si}-\mathrm{O}-\mathrm{Si}$ ) in the region $676-700 \mathrm{~cm}^{-1}$ and bending vibration ( $\mathrm{Si}-\mathrm{O}-\mathrm{Si}$ and $\mathrm{O}-\mathrm{Si}-\mathrm{O}$ ) in the region of $430-445 \mathrm{~cm}^{-1}$ [46].

For FTIR spectra of alkali-activated geopolymer mortar mix without MWCNT cured at various ages Fig. 5 indicates broadness increase of the asymmetric band at $975 \mathrm{~cm}^{-1}$ up to 90 days, which accompanied with the decrease in the asymmetric band at about $1100 \mathrm{~cm}^{-1}$ for nonsolubilized slag particles giving an indication about increased dissolution of the unreacted materials with time and increased amorphous constituents. This is in coherent with the decrease in the symmetric vibration of $\alpha$ - quartz at about $797 \mathrm{~cm}^{-1}$ with time. An increased broadness and intensity of the hydration CSH band at about $3400 \mathrm{~cm}^{-1}$ is in agreement with the XRD data interpretation (Fig. 3).

An increase in the carbonation bands in the regions of $1430 \mathrm{~cm}^{-1}(\nu \mathrm{C}-\mathrm{O})$ as well as $867 \mathrm{~cm}^{-1}(\delta \mathrm{C}-\mathrm{O})$ [57] observed with MWCNT ratio more than $0.1 \%$, where the carbonate constituents in slag materials lead to the growth of the carbonate band as discussed above, showing that the carbonates identified in this raw material do not react significantly under alkaline activation conditions [58].

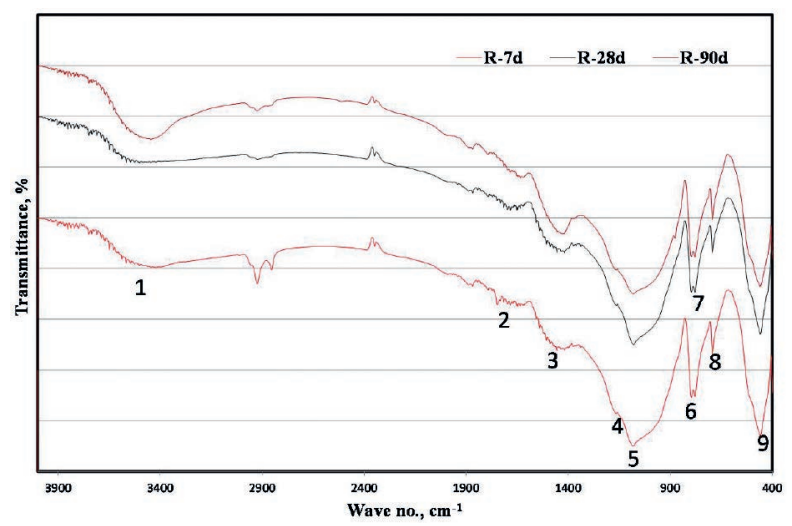

Fig. 5. FTIR spectra of geopolymer mortar mix without MWCNT at different curing ages, cured at $40{ }^{\circ} \mathrm{C}$ and $100 \% \mathrm{RH}$

[1: Stretching vibration of $\mathrm{O}-\mathrm{H}$ bond, 2: Bending vibrations of $(\mathrm{HOH}), 3$ : Stretching vibration of $\mathrm{CO}_{2}$, 4: Asymmetric stretching vibration (Si-O-Si), 5: Asymmetric stretching vibration (T-O-Si), 6: Symmetric stretching vibration (Si-O-Si) attributed to $\alpha$-quartz, 7: Symmetric stretching vibration (Al-O-Si), 8: Symmetric stretching vibration (Si-O-Si), 9: Bending vibration (Si-O-Si and O-Si-O)]

5. ábra Geopolimer habarcsok FTIR spektruma különböző korokban, szén nanocső adagolás nélkül, utókezelés $40{ }^{\circ} \mathrm{C}$ and $100 \%$ RH

[1: Vegyértékrezgés $\mathrm{O}-\mathrm{H}$ kötés, 2: Deformációs rezgés $(\mathrm{HOH}), 3$ : Vegyértékrezgés $\mathrm{CO}_{2}$, 4: Aszimmetrikus vegyértékrezgés (Si-O-Si), 5 Aszimmetrikus vegyértékrezgés (T-O-Si), 6: Szimmetrikus vegyértékrezgés (Si-O-Si) $\alpha$-kvarc miatt, 7: Szimmetrikus vegyértékrezgés (Al-O-Si), 8 : Szimmetrikus vegyértékrezgés (Si-O-Si), 9: Deformációs rezgés (Si-O-Si and $\mathrm{O}-\mathrm{Si}-\mathrm{O})]$

For FTIR spectra of 90 days alkali-activated geopolymer mortar mixes with various doses of MWCNT Fig. 6 illustrate increased dissolution of unreacted slag materials with MWCNT up to $0.1 \%$ as illustrated from the asymmetric band at about $1100 \mathrm{~cm}^{-1}$ for non-solubilized slag particles in addition to the symmetric vibration of $\alpha$-quartz at about $797 \mathrm{~cm}^{-1}$, this reflect nucleating efficiency increase of MWCNT up to 0.1 [59] and so increased the formation and propagation of the three dimensional structure. This is in addition to the increased broadness of the asymmetric band at $975 \mathrm{~cm}^{-1}$ for T-O-Si for the amorphous geopolymer structure.

The $\mathrm{CO}_{3}{ }^{2-}$ vibration band decreases with MWCNT up to $0.1 \%$ and then increased with further increase, this attributed to the fact that the increased nucleation of MWCNT increase the formation of geopolymer structure and decrease the availability of free $\mathrm{Na}^{+}$which will subjected to carbonation, however the 
increased content of MWCNT leads to agglomeration and so more sodium cations are available for carbonation as illustrated clearly.

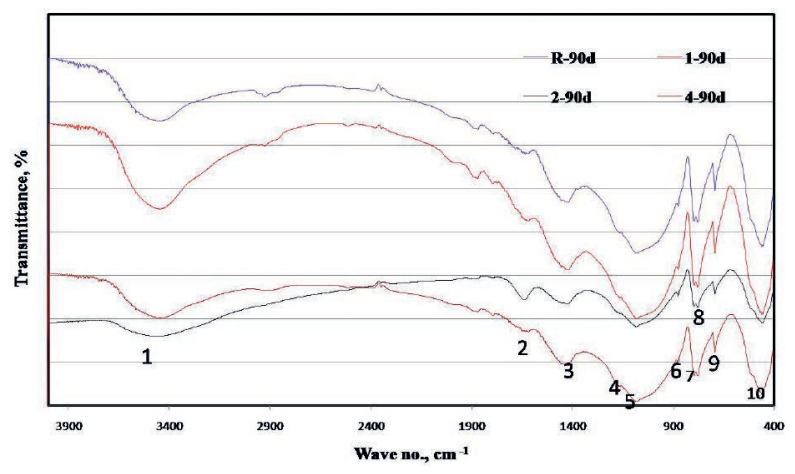

Fig. 6. FTIR spectra of 90 days cured $\left(40^{\circ} \mathrm{C}\right.$ and $100 \%$ RH) geopolymer mortar specimens having various $M W C N T$ doses

[1: Stretching vibration of $\mathrm{O}-\mathrm{H}$ bond, 2: Bending vibrations of $(\mathrm{HOH})$, 3: Stretching vibration of $\mathrm{CO}_{2}$, 4: Asymmetric stretching vibration ( $\mathrm{Si}-\mathrm{O}-\mathrm{Si}$ ), 5: Asymmetric stretching vibration (T-O-Si), 6: Symmetric stretching vibration of $\mathrm{CO}_{2}$, 7: Symmetric stretching vibration ( $\mathrm{Si}-\mathrm{O}$-Si) attributed to $\alpha$-quartz, 8: Symmetric stretching vibration (Al-O-Si), 9: Symmetric stretching vibration (Si-O-Si), 10: Bending vibration (Si-O-Si and O-Si-O)]

6. ábra Geopolimer habarcsok FTIR spektruma 90 napos korokban (utókezelés $40{ }^{\circ} \mathrm{C}$ and 100\% RH), különböző szén nanocső adagolások esetén [1: Vegyértékrezgés O-H kötés, 2: Deformációs rezgés $(\mathrm{HOH})$,

3: Vegyértékrezgés $\mathrm{CO}_{2}$, 4: Aszimmetrikus vegyértékrezgés ( $\mathrm{Si}-\mathrm{O}-\mathrm{Si}$,

5: Aszimmetrikus vegyértékrezgés (T-O-Si), 6: Szimmetrikus vegyértékrezgés $\mathrm{CO}, 7$ : Szimmetrikus vegyértékrezgés (Si-O-Si) $\alpha$-kvarc miatt,

8: Szimmetrikus vegyértékrezgés (Al-O-Si), 9: Szimmetrikus vegyértékrezgés (Si-O-Si), 10: Deformációs rezgés (Si-O-Si and O-Si-O)]

The water absorption pattern of the geopolymer mortar specimens with various MWCNT ratios cured at 7, 28 and 90 days is shown in Fig. 7, where noticeable decrease in absorption with time specially at later ages as a results of formation and precipitation of three dimensional geopolymer structure in the open pores and decrease the matrix porosity. However, the lower absorption values upon using MWCNT up to $0.1 \%$, attributed to the enhanced geopolymer formation and accumulation by carbon Nanomaterials as confirmed well by XRD and FTIR evaluations; whilst further increase in MWCNT with its agglomeration upon using higher ratios hinder the propagation and precipitation of the geopolymer network and so increase the absorption values.

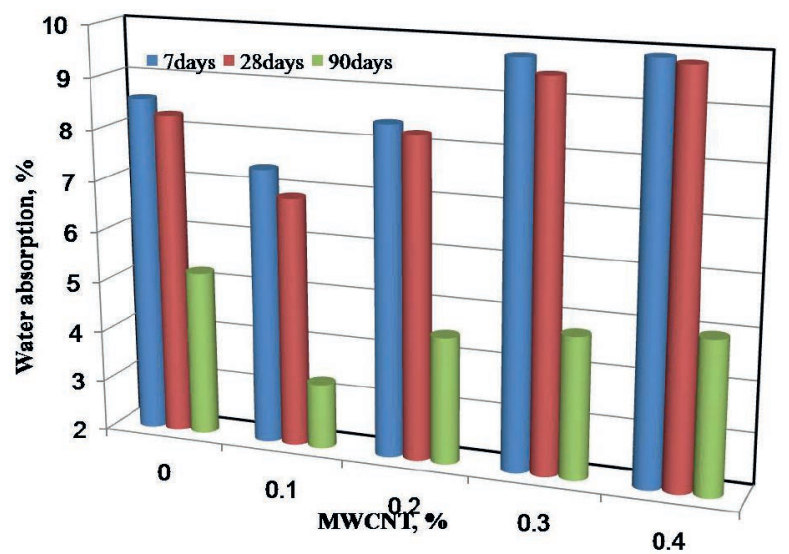

Fig. 7. Water adsorption of alkali activated geopolymer mortar specimens doped with various doses of MWCNT

7. ábra Alkáli aktivált geopolimer habarcsok vízfelvétele különbözö szén nanocső adagolások esetén
The drying shrinkage pattern of the geopolymer mortar specimens with various MWCNT ratios cured at 28 and 90 days is shown in Fig. 8, where a decrease in shrinkage with time as well as with MWCNT up to $0.1 \%$. The drying shrinkage indicates to some degree the plasticity of the mixture, as a large drying shrinkage means that mixture could absorb much water, which in turn indicates fine mixture particles [42, 43].

Most of the total drying and autogenous shrinkage take place during the early ages as illustrated from higher shrinkage values especially in the control mix, which attributed to the lower degree of geopolymerization and formation of zeolite structures with higher water content as emphasized by XRD data, this zeolite structures absorbs much water content and increase the shrinkage values. On the other hand, doping with MWCNT results in decreasing the shrinkage greatly up to $0.1 \%$ [59], where MWCNTs achieve the enhancement effect by nucleation site increase, increasing the amount of C-S-H gel of high hardness, improving pore structures, controlling nanoscale cracks and reducing autogenous shrinkage of the geopolymer composites $[34,60]$. Also, the acceleration effect of nanotubes results in the formation of more compact geopolymer structure which possess low shrinkage values, however, increased content of MWCNT results in the agglomeration and bundling in spite of sonicated dispersion $[20,60]$, which can share in an increase in the shrinkage data but still a wide gap between control mix and MWCNTs geopolymer mixes.

Drying shrinkage in composites with $0.1,0.2$ and $0.4 \%$ MWCNTs reduced to about 92, 88, 74\% after 28 days, respectively, compared with composites without CNTs (as shown in Fig. 8). Furthermore, the addition of CNTs fines the pore size distribution and decreases the porosity (or nanoporosity) of composites by filling the gaps (or pores) between the hydration products such as $\mathrm{C}-\mathrm{S}$-H gel geopolymer composite. Therefore, the composites become much more compacted [20,60]. It can be observed an increase in the drying shrinkage values with MWCNT at later ages except the lower dose of CNT (0.1\%), where the agglomeration participate greatly in the increase of the shrinkage values as stated before.

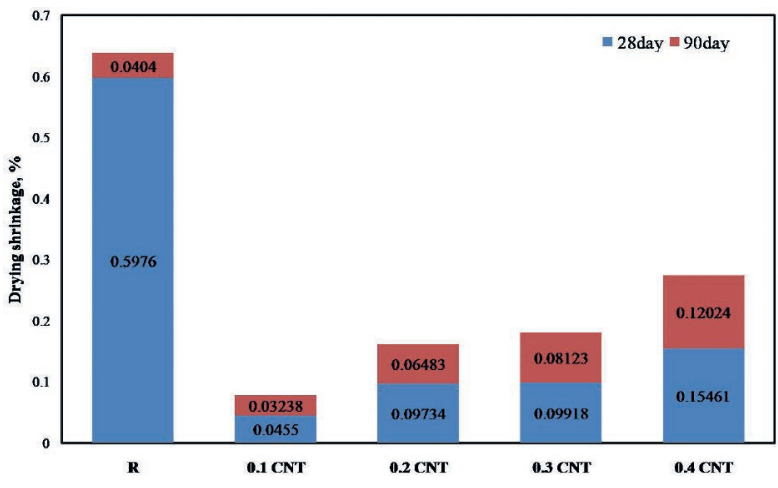

Fig. 8. Drying shrinkage of geopolymer mortars with various ratios of MWCNT at different curing ages

8. ábra Geopolimer habarcsok száradási zsugorodása eltérö érlelési korokban, különböző szén nanocső adagolások esetén

Fig. 9 shows the compressive strength of geopolymer mortar mixes enhanced with various ratios of MWCNT cured at $40^{\circ} \mathrm{C}$ and $100 \%$ relative humidity up to 90 days. The results illustrate the increase in the compressive strength with curing time as a 
result of increased hydration and propagation of geopolymer chains, also, the strength enhanced with MWCNT up to $0.1 \%$ and decrease up to $0.4 \%$.

The increase related to individual MWCNTs which spread throughout the geopolymer matrix with a uniform density. The good dispersion of MWCNTs was also attributed to the effect of the $\mathrm{NaOH}$ alkaline solution during processing as discussed [27] and hydrophilic groups (-COOH) in carboxylate based superplasticizer forming covalence-modified CNTs to improve interfacial interactions in composites, in which the $-\mathrm{COOH}$ groups form strong coordinate bonds with $\mathrm{Ca}^{2+}$ ions in matrix, thus enhancing the formation of three dimensional geopolymer in addition to $\mathrm{CSH}[56,59]$. Furthermore, the addition of CNTs fines pore size distribution and decreases the porosity (or nanoporosity) of composites by filling the gaps (or pores) between the hydration products such as C-S-H gel geopolymer composite. Therefore, the composites become much more compacted [20,60]. However, the carboxylate based superplasticizer however, was ineffective in dispersing MWCNTs at $0.2 \mathrm{~m} \%$ and more, where most of MWCNT were agglomerated in the alumino-silicate gel and hinder the propagation of the three dimensional network.

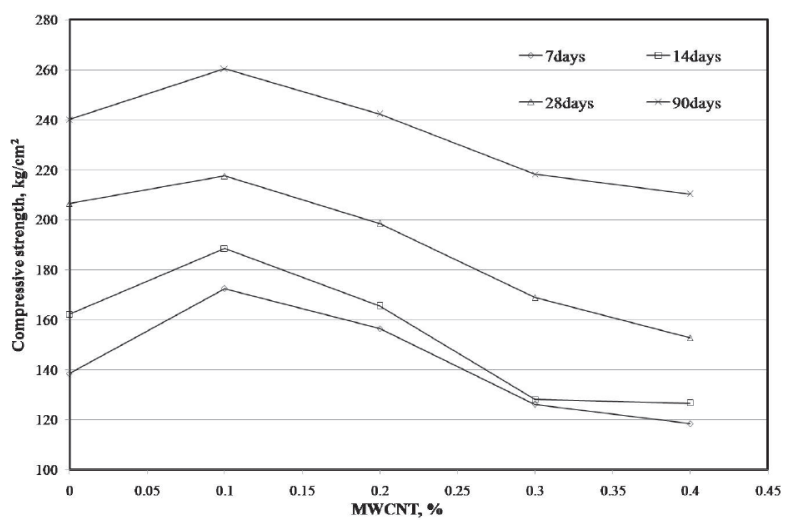

Fig. 9. Compressive strength of alkali activated geopolymer mortar specimens doped with various doses of MWCNT

9. ábra Alkáli aktivált geopolimer habarcsok nyomószilárdsága különböző szén nanocsö adagolások esetén

The results illustrate the enhancement in mechanical strength giving an increased mechanical strength than the control mix that has not MWCNT by $24.6 \%$, and $12.97 \%$, upon 7 days curing, however, these ratios decrease with further increase in curing time giving 8.46 and $0.91 \%$ after 90 curing time when using 0.1 and $0.2 \mathrm{~m} \%$ MWCNT, respectively. On the other hand, the strength decreases up on using $0.4 \mathrm{~m} \%$ MWCNT by $14.53 \%$ and $12.45 \%$ after, 7 and 90 days, respectively. The compressive strength data confirmed well by the previously discussed XRD and FTIR patterns (Figs. 3 to 6).

\section{Conclusions}

1. Adding MWCNT to alkali activated geopolymer mortar specimens increases and offers an extra nucleation sites for geopolymer formation and accumulation.

2. The $\mathrm{NaOH}$ solution appeared to have a positive effect on the dispersion quality of MWCNTs up to $0.4 \mathrm{~m} \%$.
3. XRD of mortar nanocomposites with MWCNT concentrations of 0.1 and $0.4 \mathrm{~m} \%$ showed an increase in amorphous geopolymer as well as CSH up to $0.1 \%$ where the individual MWCNTs spread throughout the geopolymer matrix with uniform density.

4. FTIR of mortar nanocomposites with MWCNT concentrations of 0.1 and $0.4 \mathrm{~m} \%$ confirms an increased broadness of amorphous geopolymer band as well as $\mathrm{CSH}$ up to $0.1 \%$.

5. MWCNT addition decreasing the water absorption values up to $0.1 \%$ and then increases with further $\mathrm{CNT}$ increase.

6. Drying shrinkage in mortar composites with $0.1,0.2$ and $0.4 \%$ MWCNTs reduced to about $92,88,74 \%$ after 28 days, respectively, compared with composites without CNTs, however an increase in the drying shrinkage values with MWCNT at later ages except the lower dose of CNT $(0.1 \%)$, where the agglomeration participate greatly in the increase of the shrinkage values.

7. The enhancement in mechanical strength with MWCNT giving an increased mechanical strength than the control mix which has not MWCNT by $24.6 \%$ and $12.97 \%$ upon 7 days curing, however, these ratios decrease with further increase in curing time giving 8.46 and $0.91 \mathrm{after}$ 90 curing time when using 0.1 and $0.2 \mathrm{~m} \%$ MWCNT, respectively. On the other hand, the strength decreases up on using $0.4 \mathrm{~m} \%$ MWCNT by $14.53 \%$ and $12.45 \%$ after, 7 and 90 days, respectively.

References

[1] Morsy, M. S. - Aglan, H. A. (2007): Development and characterization of nanostructured-Perlite-Cementitious Surface Compounds, Journal of Materials Science, Vol. 42, No. 24, pp. 10188-10195. http://dx.doi.org/10.1007/s10853-007-1981-3

[2] Aglan, H. - Morsy, M. - Allie, A. - Fouad, F. (2009): Evaluation of fiber reinforced nanostructured Perlite-cementitious surface compound for building skin applications, Construction and Building Materials, Vol. 23, No. 1, pp. 138-145. http://dx.doi.org/10.1016/j.conbuildmat.2008.01.010

[3] Shebl, S. S. - Allie, L. - Morsy, M. S. - Aglan, H. A. (2009): Mechanical behavior of activated nano silicate filled cement binders, Journal of Materials Science, Vol. 44, No. 6, pp. 1600-1606. http://dx.doi.org/10.1007/s10853-008-3214-9

[4] Lijima, S. (1991): Helical microtubes of graphitic carbon, Nature, Vol. 354, No. 7, pp. 56-58. http://dx.doi.org/10.1038/354056a0

[5] Rouainia, G. - Djeghaba, K. (2008): Evaluation of Young's modulus of single walled Carbon Nanotubes (SWNT) Reinforced Concrete Composite, Journal of Engineering and Applied Sciences, Vol. 3, No. 6, pp. 504-515. http://docsdrive.com/pdfs/medwelljournals/jeasci/2008/504-515.pdf

[6] Ando, Y. (1994): The preparation of carbon nanotubes, Fullerene Science and Technology, Vol. 2, No. 2, pp. 173-180. http://dx.doi.org/10.1080/15363839408009542

[7] Maser, W. K. - Martinez, M. T. (2002): Production of carbon nanotubes: the light approach, Carbon, Vol. 40, No. 10, pp. 1685-1695. http://dx.doi.org/10.1016/S0008-6223(02)00009-X

[8] Oncel, C., Yurum,Y. (2006) Carbon nanotubes synthesis via the catalytic CVD method: a review on the effect of reaction parameters, Fullerenes, Nanotubes, Carbon Nanostructures, Vol. 14, No.1, pp. 17-37. http://dx.doi.org/10.1080/15363830500538441

[9] Li, X. - Cao, A. - Jung, Y. J. - Vajtai, R. - Ajayan, P. M. (2005): BottomUp Growth of Carbon Nanotube Multilayers: Unprecedented Growth, Nanoletters, Vol. 5, No. 10, pp. 1997-2000. http://dx.doi.org/10.1021/nl051486q 
[10] Musso, S. - Porro, S. - Giorcelli, M. - Chiodoni, A. - Ricciardi, C. Tagliaferro, A. (2007): Macroscopic growth of carbon nanotubes mats and their mechanical properties, Carbon, Vol. 45, No. 5, pp. 1133-1136. http://dx.doi.org/10.1016/j.carbon.2006.12.019

[11] Andrews, R. - Jacques, D. - Qian, D. - Dickey, E. C. (2001): Purification and structural annealing of multiwalled carbon nanotubes at graphitization temperatures, Carbon, Vol. 39, No. 11, pp. 1681-1687. http://dx.doi.org/10.1016/S0008-6223(00)00301-8

[12] Musso, S. - Giorcelli, M. - Pavese, M. - Bavese, M. - Bianco, S. Rovere, M. - Tagliaferro, A. (2008): Improving macroscopic physical and mechanical properties of thick layers of aligned multiwall carbon nanotubes by annealing treatment, Diamond and Related Materials, Vol. 17, No. 4-5, pp. 542-547. http://dx.doi.org/10.1016/j.diamond.2007.10.034

[13] Saafi, M. - Andrew, K. - Tang, P. L. - McGhon, D. - Taylor, S. - Rahman, M. - Yang, S. - Zhou, X. (2013): Multifunctional properties of carbon nanotube/fly ash geopolymeric nanocomposites, Construction and Building Materials, Vol. 49, pp. 46-55. http://dx.doi.org/10.1016/j.conbuildmat.2013.08.007

[14] Hardjito, D. - Rangan B. V. (2005): Development and properties of lowcalcium fly ash based geopolymer concrete, Research Report GC1, Curtin University of Technology Perth, Australia

[15] Kong, D. L. Y. - Sanjayan, J. G. (2008): Damage behaviour of geopolymer composites exposed to elevated temperatures, Cement and Concrete Composites, Vol. 30, No. 10, pp. 986-991. http://dx.doi.org/10.1016/j.cemconcomp.2008.08.001

[16] Bakharev, T. (2004): Resistance of geopolymer materials to acid attack, Cement and Concrete Research, Vol. 35, No. 4, pp. 658-670. http://dx.doi.org/10.1016/j.cemconres.2004.06.005

[17] Pan, Z. - Sanjayan, J. G. - Rangan, V. (2011): Fracture properties of geopolymer paste and concrete, Magazine of Concrete Research, Vol. 63, No. 10, pp. 763-771. http://dx.doi.org/10.1680/macr.2011.63.10.763

[18] Uddin, F. - Shaik, A. (2013): Review of mechanical properties of short fibers reinforced geopolymer composites, Construction and Building Materials, Vol. 43, pp. 37-49. http://dx.doi.org/10.1016/j.conbuildmat.2013.01.026

[19] Coleman, N. J. - Khan, U. - Blau, W. J. - Gun-ko, Y. K. (2006): Small but strong: a review of the mechanical properties of carbon nanotubepolymer composites, Carbon, Vol. 44, No. 9, pp. 1624-1652. http://dx.doi.org/10.1016/j.carbon.2006.02.038

[20] Chen, S. J. - Collins, F. G. - Macleod, A. J. N. - Pan, Z. - Duan, W. H. - Wang, C. M. (2011): Carbon nanotube-cement: a retrospect, The IES Journal Part A: Civil and Structural Engineering, Vol. 4, No. 4, pp. 254-265. http://dx.doi.org/10.1080/19373260.2011.615474

[21] Tyson, B. - Abu Al-Rub, R. - Yazdanbakhsh, A. - Grasley, Z. (2011): Carbon nanotubes and carbon nano fibers for enhancing the mechanical properties of nanocomposites cementitious materials, ASCE Journal of Materials in Civil Engineering, Vol. 23, No. 7, pp. 1028-1035. http://dx.doi.org/10.1061/(ASCE)MT.1943-5533.0000266

[22] Gao, D. - Sturm, M. - Mo, Y. L. (2009): Electrical resistance of carbonnanofibre concrete, Smart Materials and Structures, Vol. 18, No. 9, pp. 1-7. http://dx.doi.org/10.1088/0964-1726/18/9/095039

[23] Collins, F. - Lambert, F. - Duan, W. H. (2012): The influence of admixtures on the dispersion, workability, and strength of carbon nanotube-OPC paste mixtures, Cement and Concrete Composites, Vol. 34, No. 2, pp. 10671074. http://dx.doi.org/10.1016/j.cemconcomp.2011.09.013

[24] Abu Al-Rub, R. K. - Tyson, B. M. - Yazdanbakhsh, A. - Grasley, Z. (2012): Mechanical properties of nanocomposite cement incorporating surfacetreated and untreated carbon nanotubes and carbon nanofibres, ASCE Journal of Nanomechanics and Micromechanics, Vol. 2, No. 1, pp. 1-6. http://dx.doi.org/10.1061/(ASCE)NM.2153-5477.0000041

[25] Kumar, S. - Kolay, P. - Malla, S. - Mishra, S. (2012): Effect of multiwalled carbon nanotubes on mechanical strength of cement paste, ASCE Journal of Materials in Civil Engineering, Vol. 24, No. 1, pp. 84-91. http://dx.doi.org/10.1061/(ASCE)MT.1943-5533.0000350

[26] Mackenzie, K. J. D. - Bolton, M. J. (2009): Electrical and mechanical properties of aluminosilicate inorganic polymer composites with carbon nanotubes, Journal of Materials Science, Vol. 44, pp. 2851-2857. http://dx.doi.org/10.1007/s10853-009-3377-z
[27] Heister, E., Lamprecht, C., Neves, V., Tîlmaciu, C., Datas, L., Flahaut, E. (2010) Higher dispersion efficacy of functionalized carbon nanotubes in chemical and biological environments, ACS Nano, Vol. 4, No. 5, pp. $2615-$ 2626. http://dx.doi.org/10.1021/nn100069k

[28] Hanjitsuwan, S. - Chindaprasirt, P. - Pimraksa, K. (2011): Electrical conductivity and dielectric property of fly ash geopolymer pastes, International Journal of Minerals, Metallurgy, and Materials, Vol. 18, No. 1, pp. 94-99. http://dx.doi.org/10.1007/s12613-011-0406-0

[29] Reich, S. - Thomsen, C. - Maultzsch, J. (2004): Carbon Nanotubes: Basic Concepts and Physical Properties, Germany Wiley-VCH, 2004.

[30] Ma, P. C. - Siddiqui, N. A. - Marom, G. (2010): Dispersion and functionalization of carbon nanotubes for polymer-based nanocomposites: a review, Composites Part A: Applied Science and Manufacturing, Vol. 41, No. 10, pp. 1345-1367. http://dx.doi.org/10.1016/j.compositesa.2010.07.003

[31] Xie, X. - Mai, Y. - Zhou, X. (2005): Dispersion and alignment of carbon nanotubes in polymer matrix: a review, Materials Science and Engineering: R: Reports, Vol. 49, No. 4, pp. 89-112. http://dx.doi.org/10.1016/j.mser.2005.04.002

[32] Fu, K. - Huang, W. - Lin, Y. (2001): Defunctionalization of functionalized carbon nanotubes, Nano Letters, Vol. 1, No. 8, pp. 439-441. http://dx.doi.org/10.1021/nl010040g

[33] Hamon, M. A. - Hui, H. - Bhowmik, P. (2002): Ester-functionalized soluble single-walled carbon nanotubes, Applied Physics A, Vol. 74, No. 3, pp. 333-338. http://dx.doi.org/10.1007/s003390201281

[34] Han, B. - Yu, X. - Ou, J. (2011): Multifunctional and smart carbon nanotube reinforced cement-based materials, Nanotechnology in Civil Infrastructure, Springer, pp. 1-47. http://dx.doi.org/10.1007/978-3-642-16657-0_1

[35] Shah, S. P. - Konsta-Gdoutos, M. S. - Metaxa, Z. S. (2011): Advanced cement based nanocomposites, Recent Advances in Mechanics, Springer, pp. 313-327. http://dx.doi.org/10.1007/978-94-007-0557-9_16

[36] Collins, F. - Lambert, F. - Duan, W. H. (2012): The influence of admixtures on the dispersion, workability, and strength of carbon nanotube-OPC paste mixtures, Cement and Concrete Composites, Vol. 34, No. 2, pp. $1067-$ 1074. http://dx.doi.org/10.1016/j.cemconcomp.2011.09.013

[37] Weitzel, B. - Hansen, M. R. - Kowald, T. L. - Müller, T. - Spiess, H. W. Trettin, H. F. R. (2011): Influence of Multiwalled Carbon Nanotubes on the Microstructure of CSH-Phases, Proceedings of 13th congress on the Chemistry of Cement, 3-8 July 2011, Madrid, Spain.

[38] El-Sayed, H. A. - Abo El-Enein, S. A. - Khater, H. M. - Hasanein, S. A. (2011): Resistance of alkali activated water cooled slag geopolymer to sulfate attack, Ceramics - Silikáty, Vol. 55, No. 2, pp. 153-160. http://www.ceramics-silikaty.cz/2011/pdf/2011_02_153.pdf

[39] Saikia, N. - Usami, A. - Kato, S. - Kojima, T. (2004): Hydration behavior of ecocement in presence of metakaolin, Resource Progressing Journal, Vol. 51, No. 1, pp. 35-41. https://www.jstage.jst.go.jp/article/rpsj/51/1/51_1_35/_pdf

[40] Taha, A. S. - El-Didamony, H. - Abo El-Enein, S. A. - Amer, H. A. (1981): Physicochemical properties of supersulphated cement pastes, ZementKalk-Gips, Vol. 34, pp. 351-353.

[41] ASTM C109M-13, Standard Test Method for Compressive Strength of Hydraulic Cement Mortars http://dx.doi.org/10.1520/C0109_C0109M

[42] Norsker, H. (1987): The Self-reliant potter: refractories and kilns, Friedr. Braunschweig/Wiesbaden: Vieweg®Sohn

[43] Ugheoke, B. I. - Onche, E. O. - Namessan, O. N. - Asikpo, G. A. (2006): Property Optimization of Kaolin - Rice Husk Insulating Fire - Bricks, Leonardo Electronic Journal of Practices and Technologies, Issue 9, JulyDecember 2006, pp.167-178.

[44] ASTM C140-01, Standard test methods for sampling and testing concrete masonry units and related units http://dx.doi.org/10.1520/C0140-01

[45] Panias, D. - Giannopoulou, I. P. - Perraki, T. (2007): Effect of synthesis parameters on the mechanical properties of fly ash-based geopolymers, Colloids and Surfaces A: Physicochemical and Engineering Aspects, Vol. 301, No. 1-3, pp. 246-254. http://dx.doi.org/10.1016/j.colsurfa.2006.12.064

[46] Vargas, A. S. - Dal Molin, D. C. C. - Masuero, A. B. - Vilela, A. C. F. - Castro-Gomes, J. - Gutierrez, R. M. (2014): Strength development of alkali-activated fly ash produced with combined $\mathrm{NaOH}$ and $\mathrm{Ca}(\mathrm{OH})_{2}$ activators, Cement and Concrete Composites, Vol. 53, pp. 341-349. http://dx.doi.org/10.1016/j.cemconcomp.2014.06.012 
[47] Ben Haha, M., Lothenbach, B., Le Saout, G. L., Winnefeld, F. (2011) Influence of Slag Chemistry on the Hydration of Alkali-Activated BlastFurnace Slag - Part I: Effect of MgO, Cement and Concrete Research, Vol. 41, No. 9, pp. 955-963. http://dx.doi.org/10.1016/j.cemconres.2011.05.002

[48] Ben Haha, M. - Le Saout, G. L. - Winnefeld, F. - Lothenbach, B. (2011): Influence of Activator Type on Hydration Kinetics, Hydrate Assemblage and Microstructural Development of Alkali Activated Blast-Furnace Slags, Cement and Concrete Research, Vol. 41, No. 3, pp. 301-310. http:// dx.doi.org/10.1016/j.cemconres.2010.11.016

[49] García Lodeiro, I. - Macphee, D. E. - Palomo, A. - Fernández-Jiménez, A. (2009): Effect of Alkalis on Fresh C-S-H Gels. FTIR Analysis, Cement and Concrete Research, Vol. 39, No. 3, pp. 147-153. http://dx.doi.org/10.1016/j.cemconres.2009.01.003

[50] García Lodeiro, I. - Palomo, A. - Fernández-Jiménez, A. - Macphee, D. E. (2011): Compatibility Studies Between N-A-S-H and C-A-S-H Gels. Study in the Ternary Diagram $\mathrm{Na}_{2} \mathrm{O}-\mathrm{CaO}-\mathrm{Al}_{2} \mathrm{O}_{3}-\mathrm{SiO}_{2}-\mathrm{H}_{2} \mathrm{O}$, Cement and Concrete Research, Vol. 41, No. 9, pp. 923-931. http://dx.doi.org/10.1016/j.cemconres.2011.05.006

[51] Bakharev, T. - Sanjayan, J. G. - Cheng, Y. B. (1999): Effect of elevated temperature curing on properties of alkali-activated slag concrete, Cement and Concrete Research, Vol. 29, No. 10, pp. 1619-1625. http://dx.doi.org/10.1016/S0008-8846(99)00143-X

[52] Malolepszy, J. (1993): Proceedings of 3rd International Symposium on Cement and Concrete. Beijing, China.

[53] Duxson, P. - Provis, J. L. - Lukey, G. C. - van Deventer, J. S. J. - Separovic, F. - Gan, Z. H. (2006): ${ }^{39} \mathrm{~K}$ NMR of Free Potassium in Geopolymers, Industrial and Engineering Chemistry Research, Vol. 45, No. 26, pp. 9208 9210. http://dx.doi.org/10.1021/ie060838g

[54] Fernández-Díaz, L. - Fernández-González, À. - Prieto, M. (2010): The role of sulfate groups in controlling $\mathrm{CaCO}_{3}$ polymorphism, Geochimica et Cosmochimica Acta, Vol. 74, No. 21, pp. 6064-6076. http://dx.doi.org/10.1016/j.gca.2010.08.010

[55] Li, Y. - Wang, P. - Zhao, X. (2006): Mechanical behaviour and microstructure of cement composites incorporating surface-treated multi-walled carbon nanotubes, Carbon, Vol. 43, No. 6, pp. 1239-1245. http://dx.doi.org/10.1016/j.carbon.2004.12.017

[56] Peyvandi, A. - Soroushian, P. - Abdol, N. (2013): Surface-modified graphite nanomaterials for improved reinforcement efficiency in cementitious paste. Carbon, Vol. 63, No. , pp. 175-186. http://dx.doi.org/10.1016/j.carbon.2013.06.069

[57] Garcia-Lodeiro, I. - Fernandez-Jimenez, A. - Palomo, A. - Macphee, D. E. (2010): Effect on fresh CS-H gels of the simultaneous addition of alkali and aluminum, Cement and Concrete Research, Vol. 40, No. 1, pp. 27-32. http://dx.doi.org/10.1016/j.cemconres.2009.08.004
[58] Bernal, S. A. - Rodríguez, E. D. - Gutiérrez, R. M. - Provis, J. L. - Delvasto, S. (2012): Activation of Metakaolin/Slag Blends Using Alkaline Solutions Based on Chemically Modified Silica Fume and Rice Husk Ash, Waste and Biomass Valorization, Vol. 3, pp. 99-108.

http://dx.doi.org/10.1007/s12649-011-9093-3

[59] Jiang, X. - Kowald, T. - Staedler, T. - Trettin, R. (2005): Carbon nanotubes as a new reinforcement material for modern cement-based binders, RILEM Proceedings, 2nd International Symposium on Nanotechnology in Construction, 2005, pp. 209-213.

[60] Parveen, S. - Rana, S. - Fangueiro, R. (2013): A review on nanomaterial dispersion, microstructure and mechanical properties of carbon nanotube and nanofiber reinforced cementitious composites, Journal of Nanomaterials, Volume 2013, Article ID 710175, 19 p. http://dx.doi.org/10.1155/2013/710175

$\underline{\text { Ref.: }}$

Khater, Hisham M. M. - Gawwad, Hamdy A. Abdel: Characterization of alkali activated geopolymer mortar doped with MWCNT Építőanyag - Journal of Silicate Based and Composite Materials, Vol. 67, No. 2 (2015), 38-47. p. http://dx.doi.org/10.14382/epitoanyag-jsbcm.2015.7

\section{MWCNT adalékos alkáli aktivált geopolimer} habarcsok tulajdonságai

A cikkben a szerzôk azt tanulmányozzák, hogy milyen hatással van a szén nanocsố adagolás az alkáli-aktivált geopolimer habarcsokra. Bizonyítják, hogy a szén nanocsố adagolás kedvezôen hat a geopolimer kristályképzôdésére, mert a szén nanocsövek kristályindító csírákként tudnak múködni. A NaOH pozitív hatást gyakorol a szén nanocsövek diszpergálhatóságára 0,4m\% adagolásig. Röntgendiffrakciós és FTIR vizsgálatokkal igazolják, hogy a szén nanocsố adagolás 0,1 és 0,4 m\% mennyiségben növeli a geopolimer amorf fázisának és CSH fázisának mennyiségét és egyenletes eloszlást biztosít. A szén nanocsô adagolás hatására a geopolimer habarcsok vízfelvétele megnô. A száradási zsugorodás, különösen késối korokban, megnố a szén nanocsố adagolás hatására. A szén nanocsố adagolás hatására az alkáli-aktivált geopolimer habarcsok nyomószilárdsága megnô.

Kulcsszavak: MWCNT, geopolimer, habarcs, vízzel lehútött salak, levegôvel lehútött salak.

\section{GP-Camp 2015}

Keynote Conferences in video:

http://www.geopolymer.org/conference/gpcamp/gp-camp-2015

PROGRAMME

Keynote by Joseph Davidovits: State of the Geopolymer R\&D 2015

Keynote by Henk Nugteren, TU Delft, The Netherlands:

Geopolymer coating of bacteria-containing granules

for use in self-healing concrete.

Session 1: Geopolymer molecular chemistry, scientific investigations, raw materials.

Session 2: industrial applications (foamed panels, ceramics,

high temperature, binders, composites, toxic and radioactive waste containment)

Session 3: building applications, LTCS, bricks, cements, concretes, Eco-building, etc.
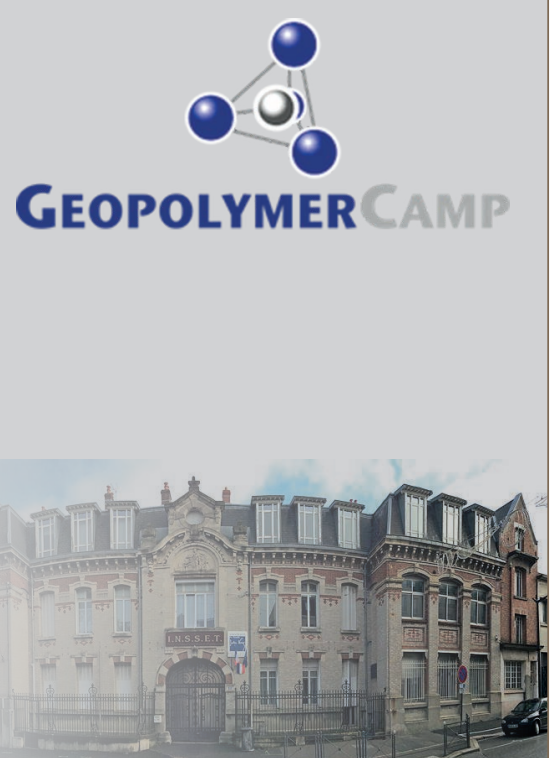